\title{
The Teaching Reform and Innovation of Chinese Tourism Geography Course in Vocational College
}

\author{
Zhang Min \\ Hebei Women's Vocational College, Shijiazhuang, Hebei, China \\ greenmain@126.com
}

Keywords: Reform, Innovation, Chinese Tourism Geography, Vocational College

\begin{abstract}
After analysing the characters of Tourism Geography and some teaching problems, the article gives some advice on teaching reform and innovation of the course from the angle of the guide's professional ability. The advice contains: carrying out module teaching by organizing teaching material; innovating teaching methods by using modern educational techniques; improving the teaching result by using modern teaching methods; building practice base and strengthening the practice teaching; innovating evaluating methods.
\end{abstract}

\section{Introduction}

Tourism has "sunrise industry," said, with the continuous improvement of economic development, scientific progress and people's living standards and the development of tourism in the national economy is more and more important. Tourism Geography Curriculum in Vocational Colleges as a tourism professional basic course, the only constant reform and innovation to adapt to the rapid development of tourism demand for specialized personnel.

\section{The Features of Travel Geography Curriculum}

Comprehensive. Tourism Geography is the study of tourism and tourism-environment relationship of science, its research contents include: basic dynamic tourism; tourism environment and space; the impact of tourism on people's residence; run tourism; tourism organization, transport, economic and social significance; tourism planning. Research on tourist travel motivations and demands need to involve psychology, economics, tourism, science and other disciplines; of tourism resources to understand and evaluate the need to learn geography, history, sociology and other disciplines theory; and tourism and tourist facilities The plan is inseparable from the support of the Disciplinary Theory of architecture, horticulture, aesthetics, and environmental science. Visible, tourism geography is a comprehensive discipline.

Regional. As important tourism geography research object of tourism resources is always present in a certain geographical area, subject to certain natural and social history of conditionality. In the current tour has developed into a global social and economic activities in the background, study tourism resources of the region, conditions, and development of tourism resources development strategy will be a major issue related to regional economic and social development. Tourism has obvious regional geography.

Applicability. Travel within the scope of application of geography close relationship with land improvement, land planning, urban and rural construction, environmental planning application disciplines. Regional tourism circuit design, tourism product development, etc., required geography methods and theories to study tourism phenomenon, ultimately serve the development of tourism.

The basic theory. Tourist geography as a comprehensive, applied discipline that requires basic theory as a support, such as the theory of tourist behavior, travel demand theory, evaluation methods and tourism life cycle and spatial competition theory of tourism resources and the like. Thus, tourism professionals in the tourism geography Vocational Colleges positioned as a professional basic course. 


\section{The Situation Analysis of Chinese Tourism Geography Teaching}

With the social and economic development, people's living standards are improving, especially the knowledge economy and the emergence of the network, Tourism Geography Teaching Higher Colleges situation more and more suited to the socio-economic development and market demand. Mainly as follows:

China's current tourism geography textbooks Subjects using the first (theoretical part) was divided on the (China's 11th largest tourist region) choreography of way for a systematic and convenient for teachers to teach subjects considered excessive, while professional competence oriented Higher Colleges of talents targeting and market positioning tourism professionals need to consider much, is not conducive to the cultivation of Vocational College students' Comprehensive Quality and professional ability.

Teaching concept is behind and it lacks reform and innovation. Teaching still continue the tradition of teaching concepts, models and methods to discipline-centered, knowledge-centered, classroom-centered, textbook-centered, teacher-centered teaching model is still the mainstream teaching.

The teaching method is outdated and teacher in school is "a lesson plan, a piece of chalk, a mouth." Teachers talk about attractions, students imagined, not perceptions, students are not enthusiastic about learning poor results.

Mainstream way students learn is still a teacher taught mainly to mechanical memory-based, content-based books. This old way of learning, mainly as follows: Teachers are always the podium, "dominate", 90\% of the time are teachers on classroom activities, and students in the "You speak my mind," the situation; learning emphasis on the conclusion of the master, neglect Cognitive Strategy implementation process complex thought process and conclusions obtained activities, emphasis on the accumulation of knowledge and neglect, spiritual, methods, attitudes culture; focus on theoretical knowledge of learning, while ignoring the operational, practical knowledge.

Due to objective conditions and lack of school funding constraints, teacher education opportunities to go out less, and few contacts with tourism businesses and professionals, we do not know the outside world more exciting, just book knowledge, lack of social practice and experience, narrow range of knowledge, teaching poor results.

\section{The Reform and Innovation of China Tourism Geography Teaching}

The integration of teaching contents and the implementation of modular teaching. Modularity is a major feature of CBE teaching. CBE is shorthand Competency Based Education, Chinese translated as competency-based education. It is based on "mastery learning" and "feedback Teaching Principles" and the famous psychologist Bloom "target classification theory" as the basis, the development of a new educational model, 1990s gradually implemented in all countries. "CBE is engaged in have the ability as a starting point to determine the mode of training and education objectives, the design of teaching content, method and process to assess teaching effectiveness of a vocational education required for a particular occupation."

Geography and tourism-related guides constitute professional competence are: First, tourism resource analysis, explain capacity; the second is tourism circuit design capability; the third is the protection of tourism resources, the capacity of the environment. [2] The three professional capacity goal, teaching content of Chinese Tourism Geography can be integrated to become five modules: Introduction to tourism resources modules (including an overview of tourism resources, natural tourism resources and cultural tourism resources, tourism resources appreciation); Tourism Design Module (including travel maps and traffic, the basic theory of circuit design); partition Tourism Geography modules (China's 11th largest tourist region); tourism resources and tourism environment protection module (including tourism resources development and protection, Good Behaviour and passenger travel behavior guide ); Local Tourism Geography module. 
After adjustment after the main features of the module: one contains the main content of Chinese tourism geography; the second is to increase the content of vocational ability development more meaningful to make more targeted vocational ability development; third is to increase the local tourism geographic content, close to the students real life, stimulate interest in learning.

The use of modern educational technology and innovative teaching methods. Psychology tells us that the strong interest in certain things or activities, there is a pilot conscious thinking activity and mental point. Full use of modern educational technology, mobilize students also participate in a variety of senses, becomes the abstract image becomes rigid as vivid, become boring for the fun becomes inefficient to efficient, help to stimulate students' thinking and interest to expand the sensing surface, made the traditional teaching methods cannot achieve teaching effectiveness.

Make full use of electronic teaching means to increase students' perceptual knowledge. Chinese Tourism Geography Curriculum is a focus of tourism professional courses, students learn through this course, to fully grasp the distribution and characteristics of China's tourism resources, and lay a good foundation for future work in the tour. At the same time it is important course in the theory and practice closely integrated. However, due to economic reasons, and many other aspects, the students during their studies all over the country going to look around are impossible. Therefore, pay special attention to the existing teaching equipment for use in classroom teaching.

Use the multimedia teaching methods. Multimedia is the digital way, with the graphics, text, audio and video, animation and moving images and other information to the performance of teaching content and processes in place to help teachers perform or part of the teaching task. It has interactive, scientific, high efficiency and good repeatability study. For a comprehensive and strong regional characteristics in terms of tourism geography curriculum, especially for the use of multimedia teaching methods. The use of multimedia teaching across the boundaries of time and space, to help students build the cognitive features of the object, the tourism geography lesson that span of time and space with abstract pictures, images, sound and other multimedia means vividly displayed on the screen, making the original difficult to understand and accept the knowledge becomes easy to understand and remember. At the same time, it can also enhance students' enthusiasm and interest.

The use of modern teaching methods to improve teaching effectiveness. China Tourism Geography Teaching, a series of topics can be designed for different teaching content. By learner collaboration, discussion to analyze the problem, collect information to determine the program until solve problems. For example, the regional tourism geography teaching, allowing students according to the distribution of the major tourist attractions in the region designed to reflect the theme of the most characteristic tourism resources of the region's best tourist routes, arrange transport journeys and to guide capacity to Visitors to explain these attractions. Again, by collecting a large variety of typical landform tourism resources pictures, ask students to teaching and learning content other written material, to determine what type of these pictures are tourism resources, based on the judgment requires students to explain this kind of tourism resources genesis, morphology and aesthetic characteristics.

Curriculum organization called pedagogy, simply put, is from a number of strengths in the research of teachers and even government agencies can be recruited in one area has a wealth of practical experience of government officials to complete the tour Geography Teaching a teaching method. Each penetration and integration of tourism geography and sociology, folklore, archeology, history, architecture, landscape architecture, economics, is evolving into an interdisciplinary, with strong comprehensive. However, tourism geography as a new branch of geography, although the development of fast, but many colleges widespread problem of insufficient teachers. Course organized by pedagogy, can take full advantage of government, tourism enterprises and human resources of the university, so that experts in various fields into the university classroom, so that students receive a quality education. Colleges and universities according to their actual situation can be bold attempt in this regard.

Scenario simulation teaching method emphasizes student learning through scenarios, to take the initiative to explore, take the initiative to find, so as to obtain experience, knowledge and effective internalization. The fundamental starting point is to be able to learn socialization, and stressed the 
independent experience of learners in the learning community, and its core content should include contextual learning, scene experience, situational exchange and reflection. Chinese tourism geography learning should not be from concept to concept, from theory to learning theory, but should be based on the creation of certain tourist scene specific content so that learners face more practical problems through learning; by themselves questions to the practical application of the knowledge gained understanding of concepts and principles. Modern psychology when people learn roles bear some responsibility, motivation to learn will be strengthened, will behave more active. Students through role-playing simulation activities, either fully demonstrate all aspects of talent, but also trained a professional interest and quality.

Establish a training base, strengthening practice teaching. Comprehensive Practice to guide professional capacity of professional competence for the purposes of training must be through practical activities associated with certain professional positions gradually formed, it cannot rely on that can deliver even the way to instill knowledge to grasp like. Although the subject of learning and scenario simulation study, the design problem is based on a real practical strong professional background tasks and issues, but in the end with the analog color. Vocational Ability should be carried out, it must provide an opportunity for students to practice. To strengthen tourism institutions and professional colleges, enterprises, establish their own practice base, to provide a guarantee for the practice of teaching.

\section{Conclusion}

With the development of modern tourism and the rise of tourism geography, tourism geography curriculum has become one of the important basic professional courses in Tourism Management in Higher Vocational Colleges. In recent years, the teaching content of tourism geography curriculum is constantly enrich in higher vocational colleges, teaching methods and teaching ways are constantly updated, the overall effect of teaching has also been greatly improved. However, tourism geography course as a young discipline, there are still a lot of content which is not perfect from teaching contents to teaching methods and it also needs to continue to carry out reform and innovation.

\section{References}

[1] R. Q. Huang, The featuresof capability-based vocational education, J. Foreign Education. 44 (2010) 146-147.

[2] D.Lin, The reform of tourism geography teaching in higher vocational colleges, J. Fujian Geography. 18(2005) 55-57.

[3] F.Liu, The review on tourism geography in china's development, J. Educational Research, 32(2012) 189-190.

[4] J.W.Zhang, The construction of knowledge-based problem solving, J, Educational Research, $4(2007) 38-40$.

[5] X.F.Tong, The new teaching methods: course organization teaching, J. Chinese University Education, 9(2013) 142-150. 